\title{
Mitochondrial DNA suggests the existence of two distinct species in Moluccas and New Guinea within Nyctimystes infrafrenatus (Günther, 1867)
}

\author{
TAUFAN NURZAMAN SULAEMAN ${ }^{1, \vartheta}$, AMIR HAMIDY, ${ }^{2, v v}$, ACHMAD FARAJALLAH ${ }^{3, v v v, ~}$ \\ ANTOINE FOUQUET $^{4}$, AWAL RIYANTO ${ }^{2}$, EVY ARIDA ${ }^{2}$, MULYADI $^{2}$, WAHYU TRILAKSONO ${ }^{2}$, \\ MISBAHUL MUNIR ${ }^{5}$ \\ ${ }^{1}$ Graduate School of Animal Bioscience, IPB University, Kampus IPB Dramaga, Bogor 16680, West Java, Indonesia. \\ vemail: taufan_sulaeman@apps.ipb.ac.id. \\ ${ }^{2}$ Zoology Division (Museum Zoologicun Bogoriense), Indonesian Institute of Sciences. Jl. Raya Jakarta-Bogor Km 46, Cibinong, Bogor 16911, West \\ Java, Indonesia. Tel.: +62-21-8765056; •vemail: hamidyamir@gmail.com, amir.hamidy@lipi.go.id. \\ ${ }^{3}$ Department of Biology, Faculty of Mathematics and Natural Sciences, Institut Pertanian Bogor. Jl. Agatis, Kampus IPB Dramaga, Bogor 16680, West \\ Java, Indonesia. Tel./fax.: +62-251-8622833; **vemail: achamad@apps.ipb.ac.id \\ ${ }^{4}$ Laboratoire Evolution et diversite biologique (EDB), UMR5174, CNRS-UPS-IRD, Bat. 4R1, Universite Paul Sabatier. Toulouse, France \\ ${ }^{5}$ Graduate School of Global Environmental Studies, Kyoto University. Yoshida-Honmichi, Sakyo-ku, Kyoto 606-8501, Japan
}

Manuscript received: 23 November 2020. Revision accepted: 18 July 2021.

\begin{abstract}
Sulaeman TN, Hamidy A, Farajallah A, Fouquet A, Riyanto A, Arida E, Mulyadi, Trilaksono W, Munir M. 2021. Mitochondrial DNA suggests the existence of two distinct species in Moluccas and New Guinea within Nyctimystes infrafrenatus (Günther, 1867). Biodiversitas 22: 3287-3297. Nyctimystes infrafrenatus is a widespread frog species distributed across northern Australia, New Guinea, Bismarck archipelago and in the eastern part of Indonesia archipelago. The species thus encompasses two biogeographic regions, Papua and Wallacea. We evaluated the phylogenetic relationships among the populations from Papua and Moluccas based on two mitochondrial loci (16S rRNA and Cytochrome Oxidase Subunit I). Two major subclades are recovered within Nyctimystes infrafrenatus with subclade A being represented by populations from New Guinea and northern Australia and subclade B by Moluccan populations (Halmahera and Tidore). Genetic distances (2.3-4.2\% in 16S rRNA) between these subclades suggest they could belong to distinct species. Since New Guinea populations correspond to the nominal species and that Nyctimystes tennuigranulatus (Boettger 1895), currently considered as a junior synonym of Nyctimystes infrafrenatus, is available for the northern Moluccan populations, we proposed to remove this taxon from synonymy. However, samples used in this study come from northern Moluccas, further studies including samples from Ambon (where another synonym was described i.e. Calamita dolichopsis) is needed to determine the taxonomic status of the southern Moluccan population whether they are conspecific with northern Moluccan population or not.
\end{abstract}

Keywords: 16S rRNA, COI, Moluccas, Litoria, Papua

\section{INTRODUCTION}

Nyctimystes infrafrenatus (white-lipped tree frog) was originally described by Günther (1867) as Hyla infrafrenata (holotype BMNH 1947.2.24.11) based on a specimen collected from Cape York Peninsula, Australia. Nyctimystes infrafrenatus was for long time placed in the genus Litoria Tchudi, 1838 (Tyler 1968; Tyler 1971; Tyler and Davies 1978). Based on molecular analysis (Wiens et al. 2010; Pyron and Wiens 2011; Duellman et al. 2016) the species has recently been transferred to Nyctimystes Stejneger, 1916 (Duellman et al. 2016). However, many other authors do not accept this revised generic arrangement for the Pelodryadidae (e.g. Kraus 2018). Nevertheless, the name Nyctimystes infrafrenatus was later accepted by Dubois and Fretey (2016) and Frost (2020).

Many taxa have been synonymised with $N$. infrafrenatus. Two months after Günther's description of Hyla infrafrenata, Cope (1867) described Calamites dolichopsis from Ambon, Indonesia. In 1878, two species that were similar to $H$. infrafrenata were described as Pelodryas militarius (Ramsay 1878) from New Ireland and Litoria guttata (Macleay 1878) from Katow, Papua New Guinea (PNG) which later considered as the synonym of $H$. infrafrenata (Fry 1913; Van Kampen 1923). Boulenger (1882) considered P. militarius (Ramsay 1878) as a junior name of C. dolichopsis (Cope 1867) and placed it in the genus Hyla as Hyla dolichopsis. Later, two variants of $H$. dolichopis were described. Hyla dolichopsis var. tennuigranulata from Halmahera and Ternate, Moluccas (Maluku) (Boettger 1895) and Hyla dolichopsis var. pollicaris from Bismarck Archipelago (Werner 1898). Hyla dolichopsis and $H$. dolichopsis var. tennuigranulata were later considered as synonyms of Hyla infrafrenata (Boulenger 1912; Van Kampen 1919). In 1912, Boulenger considered $H$. dolichopsis var. pollicaris similar to which was firstly described as Pelodryas militarius (synonym of H. dolichopsis). He proposed the epithet name "militarius" which was proposed by Ramsay (1878) to be used in this New Ireland-type Hyla as Hyla militaria which was later considered as synonym of $H$. infrafrenata. In the same 
publication, Boulenger also described a new species named Hyla spengeli from Dinawa, PNG which later synonymized to $N$. infrafrenatus by Loveridge (1948).

Two subspecies were recognized as Nyctimystes infrafrenatus infrafrenatus and Nyctimystes infrafrenatus militarius (Tyler 1971). N. infrafrenatus militarius occurs in New Britain and New Ireland islands in the Bismarck Archipelago (Loveridge 1948; Tyler 1971; Iskandar and Colijn 2000; Menzies 2006). N. infrafrenatus militarius can be diagnosed by rudimentaray pollux on the male (Tyler 1971; Ramsay 1878; Werner 1989). Nyctimystes infrafrenatus infrafrenatus is widely distributed from the Moluccas (including Kei, Ambon, Obi, Buru, Seram, Morotai and Halmahera), Talaud Island, Timor Island, the New Guinea (including Aru, Waigeo, Misol, and Tanimbar) and north-eastern Australia (Boulenger 1912; Brongersma 1948; Tyler 1978; Iskandar and Colijn 2000; Menzies 2006; Setiadi and Hamidy 2006; Hamidy and Mulyadi 2007; Koch et al. 2007; Iskandar et al. 2017; Karin et al. 2018; Nugroho et al. 2019; Frost 2020).

Interestingly, morphometric analysis showed slight variation in the size of the female between the Moluccas and the New Guinea populations of $N$. infrafrenatus infrafrenatus (Prafiadi et al. 2016). These two groups of populations are isolated by minimum $47 \mathrm{~km}$ of saltwater (Gebe Is. to Halmahera), a very efficient barrier for amphibians (Fonte et al. 2019). Moreover, past land bridges are ancient and these land masses (especially Halmahera) have not been in contact recently (Hall and Nichols 1990; Setiadi et al. 2010). Therefore, we assume that the previously observed morphological differences could be resulting from ancient events (Van der Kaars 1991; Hantoro et al. 1995; Voris 2000; Yokoyama et al. 2001) and possibly indicative of specific differentiation.

Here we examined phylogenetic relationships between the Moluccan and the Papuan populations of $N$. infrafrenatus infrafrenatus using $16 \mathrm{~S}$ rRNA and Cytochrome Oxidase Subunit I (COI) genes which both are the most universally used genes for amphibians barcoding and phylogenetic analysis (Vences et al. 2005).

\section{MATERIALS AND METHODS}

\section{Study area}

Our study area was focused on Indonesian, including part of the Moluccas (Halmahera and Tidore) and Papua (including Raja Ampat). Additional data for both ingroups and outgroups were added from Papua New Guinea and Australia (Figure 1).

\section{Materials}

We generated partial sequence data of the mitochondrial DNA genes $16 \mathrm{~S}$ rRNA $(\mathrm{n}=25)$ and Cytochrome Oxidase Subunit 1 (COI) $(\mathrm{n}=41)$ of $N$. infrafrenatus, representing populations from Moluccas, Papua and Australia. We added outgroups from the same genus e.g. Litoria pallidofemora [now Nyctimystes pallidofemora (Kraus 2018)], Litoria purpureolata [now Nyctimystes purpureolatus (Oliver et al. 2007)], from the different genera in the same family e.g. Litoria rheocolus [now Ranoidea rheocola (Liem 1974)], Hyla nannotis [now Ranoidea nannotis (Andersson 1916)], Rana caerulea [now Ranoidea caerulea (White 1790)], Hyla gracilenta [now Ranoidea gracilenta (Peters 1869)], Litoria bella [now Ranoidea bella (McDonald et al. 2016)], Litoria auae [now Ranoidea auae (Menzies and Tyler 2004)], Hyla arfakiana [now Litoria arfakiana (Peters and Doria 1878)], Hyla angiana [now Litoria angiana (Boulenger 1915)] and Hyla amboinensis [now Litoria amboinensis (Horst 1883)]. We also included outgroup from different family e.g. Papurana volkerjane (Günther 2003), Asterophrys turpicola (Schlegel 1837), Callulops robustus (Boulenger 1898), Limnodynastes terraereginae Fry, 1915 (Dubois and Fretey 2016; Duellman et al. 2016; Frost 2020) (Table 1). Specimens were collected from northern Moluccas, Waigeo, West Papua and Papua Province. Voucher specimens and/ or tissues are stored in Museum Zoologicum Bogoriense (MZB), Research Center for Biology-Indonesian Institute of Sciences.

\section{Procedures \\ Preparation of DNA, PCR and DNA sequencing}

Genomic DNA was extracted using a PhenolChloroform extraction procedure (Hillis et al. 1996). We homogenised tissues in $0.6 \mathrm{ml}$ STE buffer containing 10 $\mathrm{mM}$ Tris/ $\mathrm{HCl}, \mathrm{pH} 8.0,100 \mathrm{~m} \mathrm{MNaCl}$ and $1 \mathrm{mM}$ EDTA, $\mathrm{pH}$ 8.0. We added Proteinase $\mathrm{K}(0.1 \mathrm{mg} / \mathrm{ml})$ to the homogenate solutions and digested proteins between 4 (four) to $12 \mathrm{~h}$ at $55^{\circ} \mathrm{C}$. The solution was treated with phenol and chloroform/ isoamyl alcohol and DNA was precipitated with ethanol. DNA precipitates were dried and then resuspended in $0.6 \mathrm{ml}$ TE $(10 \mathrm{mMTris} / \mathrm{HCl}, 1 \mathrm{mM}$ EDTA, $\mathrm{pH}$ 8.0) and $1 \mu \mathrm{l}$ was used in polymerase chain reaction (PCR). The $\mathrm{PCR}$ cycle included an initial denaturation step of $5 \mathrm{~min}$ at $94^{\circ} \mathrm{C}$ and 33 cycles of denaturation for 30 seconds at $94^{\circ} \mathrm{C}$, primer annealing for 30 seconds at $48-50{ }^{\circ} \mathrm{C}$, and extension for $1 \mathrm{~min} 30$ seconds at $72^{\circ} \mathrm{C}$. Primers used in PCR are shown in Table 2. The PCR products were purified using polyethylene glycol (PEG, 13\%) precipitation procedures were used directly as templates for Cycle Sequencing Reactions with fluorescent-dye-labeled terminator (ABI Big Dye Terminators v.3.1 cycle sequencing kit). The sequencing reaction products were purified by ethanol precipitation following the manufacture's protocol and were then run on an ABI PRISM 3130 genetic analyzer. All samples were sequenced in both directions using the same primers as the PCR.

\section{Data analysis}

Both 16S rRNA and COI sequences were aligned and trimmed using MUSCLE in MEGA X (Kumar et al. 2018). The final alignment comprised of total of 419 nucleotide sites of 16S rRNA and 555 nucleotide sites of COI were examined. Phylogenetic relationships were estimated using maximum likelihood (ML) and Bayesian inference (BI). Maximum likelihood was performed in MEGA $\mathrm{X}$ with General Timer Reversible (GTR) and Gamma Shape Parameter $(\mathrm{G})$ as best fit model for $16 \mathrm{~S}$ rRNA and GTR 
with invariant site (I) for COI. This model was selected based on the results from the "Find Best Model" analysis on MEGA $\mathrm{X}$ with lower Bayesian Information Criterion (BIC) and Akaike Information Criterion (AIC) (Nei and Kumar 2000; Kumar et al. 2018). The BI analysis was implemented using MrBayes 3.2.7a (Ronquist and Huelsenbeck 2003). The substitution model for Bayesian analyses was selected from the models with the lowest AIC scores (Akaike Information Criterion) in Kakusan 3 (Tanabe 2007), with GTR+Gamma for 16S rRNA and Hasegawa-Kishino-Yano (HKY85) + Gamma for COI. BI analyses were run 10000000 Markov Chain Monte Carlo (MCMC) generations with MCMC diagnosis frequency of
100000 and a burn-in of $25 \%$. Tree topology was sampled every 1000 generations.

We used non-parametric bootstrapping (NPBS) to determine nodal support strength in ML analyses with 1000 replicates (MLBS). Nodes bootstrap values of $70 \%$ or higher were considered as strongly supported (Hillis and Bull 1993). While in the BI analysis, nodes with a Bayesian posterior probability (BPP) of $95 \%$ or greater were considered as well supported (Leaché and Reeder 2002). We also estimated the genetic distance (uncorrected pdistance) by both 16S rRNA and COI gene among populations of $N$. infrafrenatus infrafrenatus using MEGA X (Kumar et al. 2018).

Table 2. Primers used in this study

\begin{tabular}{llll}
\hline \multicolumn{1}{c}{ Target } & \multicolumn{1}{c}{ Primer } & \multicolumn{1}{c}{ Sequence (5'-3') } & Reference \\
\hline 16S rRNA & 16H-1 & CTCCGGTCTGAACTCAGATCACGTAGG & Hedges 1994 \\
& 16L-1 & CTGACCGTGCAAAGGTAGCGTAATCACT & Hedges 1994 \\
COI & LCO1490 & GGTCAACAAATCATAAAGATATTGG & Folmer et al. 1994 \\
& HCO2198 & TAAACTTCAGGGTGACCAAAAAATCA & Folmer et al. 1994 \\
\hline
\end{tabular}

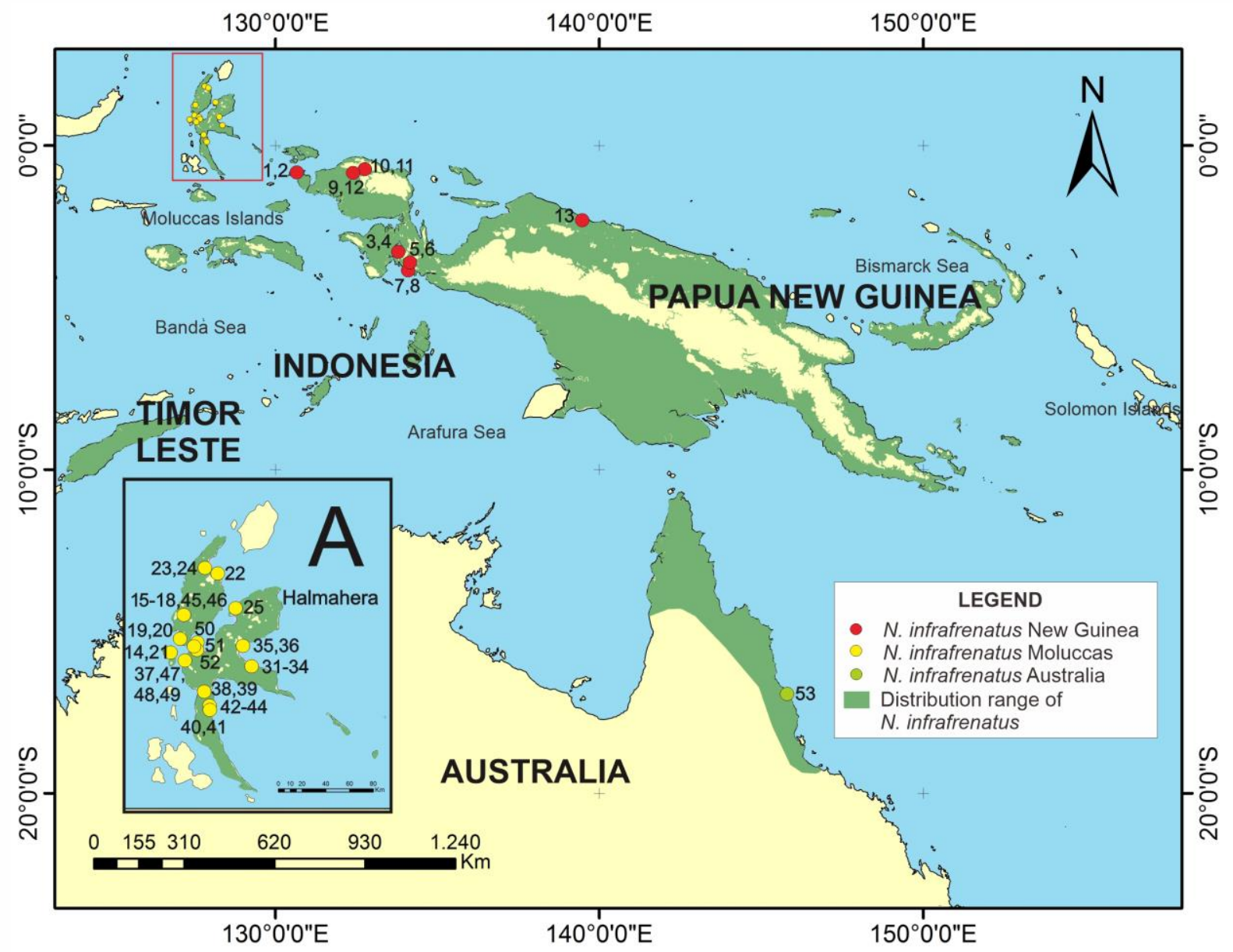

Figure 1. Map of the Moluccas, New Guinea and Australia illustrating provenance of $N$. infrafrenatus infrafrenatus mentioned in this study. Sample numbers correspond to those in Table 1 (Map modified from ArcGIS 10.3 Desktop Map, September 27, 2020 (ESRI 2014)) 
Table 1. Samples of Nyctimystes infrafrenatus and related species were used for mtDNA analysis in this study together with information on species identification, specimen voucher number, locality, GenBank accession numbers, and references

\begin{tabular}{|c|c|c|c|c|c|c|}
\hline \multirow[b]{2}{*}{ Species } & \multirow[b]{2}{*}{ Voucher } & \multirow{2}{*}{ Locality } & \multicolumn{2}{|c|}{ Gene } & \multirow{2}{*}{ Accession number } & \multirow[b]{2}{*}{ Reference } \\
\hline & & & 16S rRNA & COI & & \\
\hline N. infrafrenatus & MZB Amph 17641 & Indonesia, West Papua, Raja Ampat, Batanta Utara, Yensewai & + & - & MW410751 & This study \\
\hline N. infrafrenatus & MZB Apmh 17640 & Indonesia, West Papua, Raja Ampat, Batanta Utara, Yensewai & + & - & MW410752 & This study \\
\hline N. infrafrenatus & MZB Amph 24414 & Indonesia, West Papua, Kaimana, Teluk Arguni Bawah, Urisa & + & + & MW410753, MW422136 & This study \\
\hline N. infrafrenatus & MZB Amph 24415 & Indonesia, West Papua, Kaimana, Teluk Arguni Bawah, Urisa & + & + & MW410754, MW422137 & This study \\
\hline N. infrafrenatus & MZB Amph 24399 & Indonesia, West Papua, Kaimana, Lobo & + & + & MW410755, MW422132 & This study \\
\hline N. infrafrenatus & MZB Amph 24400 & Indonesia, West Papua, Kaimana, Lobo & + & + & MW410756, MW422133 & This study \\
\hline N. infrafrenatus & MZB Amph 24944 & Indonesia, West Papua, Kaimana, Lobo & + & + & MW410757, MW422135 & This study \\
\hline N. infrafrenatus & MZB Amph 24945 & Indonesia, West Papua, Kaimana, Lobo & + & + & MW410758, MW422134 & This study \\
\hline N. infrafrenatus & MZB Amph UN-1 & Indonesia, West Papua, Tambrauw, Fef & + & - & MW410759 & This study \\
\hline N. infrafrenatus & MZB Amph 26685 & Indonesia, West Papua, Tambrauw, Miyah & + & - & MW410760 & This study \\
\hline N. infrafrenatus & MZB Amph 26694 & Indonesia, West Papua, Tambrauw, Miyah & + & - & MW410761 & This study \\
\hline N. infrafrenatus & MZB Amph 26687 & Indonesia, West Papua, Tambrauw, Fef & + & - & MW410762 & This study \\
\hline N. infrafrenatus & MZB Amph 30730 & Indonesia, Papua, Sarmi, Bonggo & + & - & MW410750 & This study \\
\hline N. infrafrenatus & MZB Amph 12696 & Indonesia, North Moluccas, Ternate, Ternate Selatan, Gambesi & + & + & MW410772, MW425689 & This study, BOLD 2020 \\
\hline N. infrafrenatus & MZB Amph 12697 & Indonesia, North Moluccas, West Halmahera, Sahu Timur, Goal & - & + & FJ952304 & Setiadi et al. 2010 \\
\hline N. infrafrenatus & MZB Amph 12698 & Indonesia, North Moluccas, West Halmahera, Sahu Timur, Goal & - & + & FJ952305 & Setiadi et al. 2010 \\
\hline N. infrafrenatus & MZB Amph UN-2 & Indonesia, North Moluccas, West Halmahera, Sahu Timur, Goal & - & + & FJ952306 & Setiadi et al. 2010 \\
\hline N. infrafrenatus & MZB Amph UN-3 & Indonesia, North Moluccas, West Halmahera, Sahu Timur, Goal & - & + & FJ952307 & Setiadi et al. 2010 \\
\hline N. infrafrenatus & MZB Amph 12699 & Indonesia, North Moluccas, West Halmahera, Tafale & - & + & FJ952308 & Setiadi et al. 2010 \\
\hline N. infrafrenatus & MZB Amph 12700 & Indonesia, North Moluccas, West Halmahera, Tafale & - & + & FJ952309 & Setiadi et al. 2010 \\
\hline N. infrafrenatus & MZB Amph 12706 & Indonesia, North Moluccas, Ternate, Ternate Selatan, Gambesi & + & - & MW410773 & This study \\
\hline N. infrafrenatus & MZB Amph 12709 & Indonesia, North Moluccas, North Halmahera, Ruko & + & + & FJ952310 & This study, Setiadi et al. 2010 \\
\hline N. infrafrenatus & MZB Amph 12710 & Indonesia, North Moluccas, North Halmahera, Seki & + & + & FJ952311 & This study, Setiadi et al. 2010 \\
\hline N. infrafrenatus & MZB Amph 12712 & Indonesia, North Moluccas, North Halmahera, Seki & - & + & FJ952312 & Setiadi et al. 2010 \\
\hline N. infrafrenatus & MZB Amph 12713 & Indonesia, North Moluccas, East Halmahera, Lolobata NP & - & + & FJ952313 & Setiadi et al. 2010 \\
\hline N. infrafrenatus & MZB Amph 12714 & Indonesia, North Moluccas, East Halmahera, Soagimalaha & + & - & MW410763 & This study \\
\hline N. infrafrenatus & MZB Amph 12715 & Indonesia, North Moluccas, East Halmahera, Soagimalaha & - & + & FJ952314 & Setiadi et al. 2010 \\
\hline N. infrafrenatus & MZB Amph 12716 & Indonesia, North Moluccas, East Halmahera, Soagimalaha & - & + & FJ952315 & Setiadi et al. 2010 \\
\hline N. infrafrenatus & MZB Amph 12718 & Indonesia, North Moluccas, East Halmahera, Soagimalaha & - & + & FJ952316 & Setiadi et al. 2010 \\
\hline N. infrafrenatus & MZB Amph 12719 & Indonesia, North Moluccas, East Halmahera, Soagimalaha & - & + & FJ952317 & Setiadi et al. 2010 \\
\hline N. infrafrenatus & MZB Amph 12723 & Indonesia, North Moluccas, East Halmahera, Soagimalaha & - & + & FJ952318 & Setiadi et al. 2010 \\
\hline N. infrafrenatus & MZB Amph 12724 & Indonesia, North Moluccas, East Halmahera, Soagimalaha & - & + & FJ952319 & Setiadi et al. 2010 \\
\hline N. infrafrenatus & MZB Amph 12725 & Indonesia, North Moluccas, East Halmahera, Soagimalaha & - & + & FJ952320 & Setiadi et al. 2010 \\
\hline N. infrafrenatus & MZB Amph 12726 & Indonesia, North Moluccas, East Halmahera, Soagimalaha & - & + & FJ952321 & Setiadi et al. 2010 \\
\hline N. infrafrenatus & MZB Amph 12730 & Indonesia, North Moluccas, East Halmahera, KM5-10 Buli & + & + & MW410764, FJ952322 & This study, Setiadi et al. 2010 \\
\hline N. infrafrenatus & MZB Amph 12731 & Indonesia, North Moluccas, East Halmahera, KM5-10 Buli & + & + & MW410765, FJ952323 & This study, Setiadi et al. 2010 \\
\hline N. infrafrenatus & MZB Amph 12732 & Indonesia, North Moluccas, Tidore Kepulauan, Oba Utara, Sofifi & - & + & FJ952324 & Setiadi et al. 2010 \\
\hline N. infrafrenatus & MZB Amph 12733 & Indonesia, North Moluccas, Central Halmahera, Weda & - & + & FJ952331 & Setiadi et al. 2010 \\
\hline N. infrafrenatus & MZB Amph 12734 & Indonesia, North Moluccas, Central Halmahera, Weda & + & + & MW410770, FJ952332 & This study, Setiadi et al. 2010 \\
\hline
\end{tabular}




\begin{tabular}{|c|c|c|c|c|c|c|}
\hline N. infrafrenatus & MZB Amph 12735 & Indonesia, North Moluccas, South Halmahera, Kluting Jaya SP4 & - & + & FJ952333 & Setiadi et al. 2010 \\
\hline N. infrafrenatus & MZB Amph 12736 & Indonesia, North Moluccas, South Halmahera, Kluting Jaya SP4 & + & + & MW410771, FJ952334 & This study, Setiadi et al. 2010 \\
\hline N. infrafrenatus & MZB Amph 12737 & Indonesia, North Moluccas, South Halmahera, Kluting Jaya SP3 & - & + & FJ952335 & Setiadi et al. 2010 \\
\hline N. infrafrenatus & MZB Amph 12738 & Indonesia, North Moluccas, South Halmahera, Kluting Jaya SP3 & - & + & FJ952336 & Setiadi et al. 2010 \\
\hline N. infrafrenatus & MZB Amph 12739 & Indonesia, North Moluccas, South Halmahera, Kluting Jaya SP3 & - & + & FJ952337 & Setiadi et al. 2010 \\
\hline N. infrafrenatus & MZB Amph 12740 & Indonesia, North Moluccas, West Halmahera, Sahu Timur, Goal & + & - & MW410766 & This study \\
\hline N. infrafrenatus & MZB Amph 12741 & Indonesia, North Moluccas, West Halmahera, Sahu Timur, Goal & + & - & MW410767 & This study \\
\hline N. infrafrenatus & MZB Amph 12744 & Indonesia, North Moluccas, Tidore Kepulauan, Oba Utara, Sofifi & - & + & FJ952325 & Setiadi et al. 2010 \\
\hline N. infrafrenatus & MZB Amph 12751 & Indonesia, North Moluccas, Tidore Kepulauan, Oba Utara, Sofifi & - & + & FJ952326 & Setiadi et al. 2010 \\
\hline N. infrafrenatus & MZB Amph 12752 & Indonesia, North Moluccas, Tidore Kepulauan, Oba Utara, Sofifi & - & + & FJ952327 & Setiadi et al. 2010 \\
\hline N. infrafrenatus & MZB Amph 12754 & North Moluccas, East Halmahera, Wasile Selatan, Musambo & - & + & FJ952328 & Setiadi et al. 2010 \\
\hline N. infrafrenatus & MZB Amph 12755 & North Moluccas, West Halmahera, Jailolo Selatan, Dodinga & - & + & FJ952329 & Setiadi et al. 2010 \\
\hline N. infrafrenatus & MZB Amph 12756 & North Moluccas, West Halmahera, Jailolo Selatan, Braha & - & + & FJ952330 & Setiadi et al. 2010 \\
\hline N. infrafrenatus & SAMA R34970 & Australia, Queensland, Cairns & + & - & FJ945394 & Rosauer et al. 2009 \\
\hline N. pallidofemora & MZB Amph 24402 & Indonesia, West Papua, Kaimana, Lobo & + & + & MW412731, MW422139 & This study \\
\hline N. purpureolatus & MZB Amph 30684 & Indonesia, Papua, Sarmi, Bonggo & + & - & MW413586 & This study \\
\hline L. amboinensis & MZB Amph 24313 & Indonesia, West Papua, Kaimana, Lobo & - & + & MW422138 & This study \\
\hline L. arfakiana & TNHC 51936 & Papua New Guinea, Madang, Kaironk Village & + & - & AY326039 & Darst \& Cannatella 2004 \\
\hline L. angiana & Clone 16La1 & Papua New Guinea, Western Province & + & - & AF136331 & Cunningham 2001 Unp. \\
\hline R. rheocola & Clone $16 \operatorname{Lr} 2$ & Australia, Queensland, Mt. Lewis, 16.7 km & + & - & AF136327 & Cunningham 2001 Unp. \\
\hline R. nannotis & Clone 16Ln5 & Australia, Queensland, O'Keefe Ck & + & - & AF136325 & Cunningham 2001 Unp. \\
\hline R. caerulea & SAMA R33448 & Australia, Queensland, Townsville & + & - & AF282609 & Mahony et al. 2001 \\
\hline R. caerulea & AY883980 & NA & - & + & AY883980 & Vences et al. 2005 \\
\hline R. gracilenta & SAMA R34600 & Australia, Queensland, Cairns & + & - & KX621218 & McDonald et al. 2016 \\
\hline R. bella & QM J74476 & Australia, Queensland, Coen, Lankelly Ck & + & - & KX621217 & McDonald et al. 2016 \\
\hline R. аиае & SAMA R69326 & Papua New Guinea, Gulf Province, Kopi & + & - & KX621221 & McDonald et al. 2016 \\
\hline P. volkerjane & RG 7724 & Indonesia, Papua, Mts. Wondiwoi & + & - & KR264105 & Oliver et al. 2015 \\
\hline P. volkerjane & MZB Amph 24409 & Indonesia, West Papua, Kaimana, Lobo & - & + & MW422140 & This study \\
\hline A. turpicola & ABTC 90180 & Indonesia, West Papua, Raja Ampat. & + & + & KM509095; KM509761 & Peloso et al. 2015 \\
\hline C. robustus & ABTC 45377 & Papua New Guinea, Southern Highland Province, Magidobo & + & + & KM509105; KM509772 & Peloso et al. 2015 \\
\hline L. terraereginae & J789 & Australia, Queensland, Rockhampton & + & - & AJ269782 & Schauble et al. 2000 \\
\hline
\end{tabular}

Texas Natural History Collection. +: present, -: absent 


\section{RESULTS AND DISCUSSION}

\section{Sequence and statistics}

The aligned 16S rRNA data set consisted of 419 characters, in which 234 sites were variable and 161 parsimony informative. Genetic distances for the $16 \mathrm{~S}$ rRNA are provided in Table 3. The aligned COI data set consisted of 555 characters, in which 221 sites were variable and 186 parsimony informative. Genetic distances for the COI are provided in Table 4.

\section{Phylogenetic relationships}

All analyses resulted in the same topologies on ML and $\mathrm{BI}$ for 16S rRNA and slightly differed with ML and BI for COI. The Bayesian tree (Figure 2) inferred the following sets of relationships: (i) Monophyly of $N$. infrafrenatus infrafrenatus as sister group of the clade formed by $N$. pallidofemora and N. purpureolatus (MLBS $=99 \%$ and $\mathrm{BPP}=100 \%$ ). (ii) Monophyly of $N$. infrafrenatus infrafrenatus with respect to $N$. pallidofemora in COI was supported in all trees (MLBS $=100 \%$ and BPP= 99\%). (iii) The clade of $N$. infrafrenatus infrafrenatus consisted of two subclades, subclade A (Papuan and Australian) (16S rRNA MLBS $=93 \% \quad \mathrm{BPP}=97 \%, \mathrm{COI}$ MLBS $=100 \% \quad \mathrm{BPP}=99 \%)$ and subclade $\mathrm{B}$ (Moluccan) (16S rRNA MLBS $=93 \%$ $\mathrm{BPP}=99 \%$, COI MLBS $100 \%, \mathrm{BPP}=99 \%$ ). (iv) An extensive genetic distance exists between the Moluccan subclade and the Papuan subclade (without Australian) (16S rRNA p-distance $=2.3-2.8 \%$, COI= 9.9-10.8\%). (v) In 16S rRNA, the Australian N. infrafenatus infrafrenatus (single sample) is genetically closer to the Papuan ( $\mathrm{p}$ distance 1.3-1.8\%) than to the Moluccan subclade (pdistance $3.9-4.2 \%)$.

Table 3. Genetic distance (p-distance) (\%) among Papuan and Moluccan population of $N$. infrafrenatus infrafrenatus and outgroup taxa based on 16S rRNA

\begin{tabular}{lcccc}
\hline & $\mathbf{1}$ & $\mathbf{2}$ & $\mathbf{3}$ & $\mathbf{4}$ \\
\hline Australia & & & & \\
Papua & $1.3-1.8$ & & & \\
Moluccas & $3.9-4.2$ & $2.3-2.8$ & & \\
N. pallidofemora & 11.3 & $10.4-10.9$ & $10.9-11.4$ & \\
N. purpureolatus & 11.5 & $10.4-10.6$ & $10.4-10.6$ & 10.7
\end{tabular}

Table 4. Genetic distance (\% p-uncorrected) among Papuan and Moluccan population of $N$. infrafrenatus infrafrenatus and outgroup members based on COI

\begin{tabular}{lcc}
\hline & $\mathbf{1}$ & $\mathbf{2}$ \\
\hline Papua & $9.9-10.8$ & \\
Moluccas & $18.0-18.4$ & $17.8-18.2$
\end{tabular}

\section{Discussion}

Our results showed that Nyctimystes infrafrenatus infrafrenatus forms a monophyletic group divided into two subclades: Moluccas vs. Papua and Australia (Figure 2) among which we recovered large genetic distance (16S rRNA 2.3-4.2\%, COI 9.9-10.8\%). Using $16 \mathrm{~S}$ rDNA, Fouquet (2007) suggested a threshold value of $3 \%$ pdistance could be used to flag candidate species. Moreover in Pelodryadidae, McDonald et al. (2016) described a new species of Ranoidea bella from Australia with $2 \%$ genetic distance to its closest relative Ranoidea auae Menzies and Tyler, from New Guinea. Our finding (2.3-4.2\% p distance in 16S rRNA) between the Moluccan and the Papuan populations matches these values. The type locality of $N$. infrafrenatus is Cape York, Australia. Our subclade A thus corresponds to the nominal species Nyctimystes infrafrenatus infrafrenatus. In order to examine the taxonomic status of the Moluccan population, the long and complex taxonomic history of Nyctimystes infrafrenatus need to be carefully explored. There are two synonyms of $N$. infrafrenatus infrafrenatus which have type localities from Moluccas. There is Calamita dolichopsis (Cope 1867) from Ambon and Hyla dolichopsis var. tennuigranulata (Boettger 1895) from Halmahera. According to the article 23 of the International Code of Zoological Nomenclature (ICZN 1999) the valid name of a taxon is the oldest available name applied to it, unless that name has been invalidated or another name is given precedence by any provision of the Code or by any ruling of the Commission. Although Calamita dolichopsis had been published earlier (1867) but all Moluccan samples involved in this phylogenetic reconstruction come from the Halmahera and Ternate, so we suggest the $H$. dolichopsis var. tennuigranulata (1895) to be applied for the northern Mollucan population as Nyctimystes tennuigranulatus (Boettger 1895).

Both populations (Papua and Moluccas) shared similar morphological characteristics. Nevertheless, previous study on morphometrics showed that the females from Moluccas have shorter hind limb (HLL) than the ones from Papua. Moreover, in the description of Hyla dolichopsis var. tennuigranulata Boettger stated that the tympanum diameter of this species is smaller than the fingers disc while for the Papuan population (refer to $H$. dolichopsis from Papua) it is larger. From the live specimen (Figure 3), the width and length of white infralabial line appear to differ among the two populations. The Papuan population sample appears to have a thicker white lip than the Moluccan, but is not consistent across all specimens (Figure 4). Further examination of morphological characteristics of both populations is needed to determine the distinctive characteristics of the Moluccan population. 


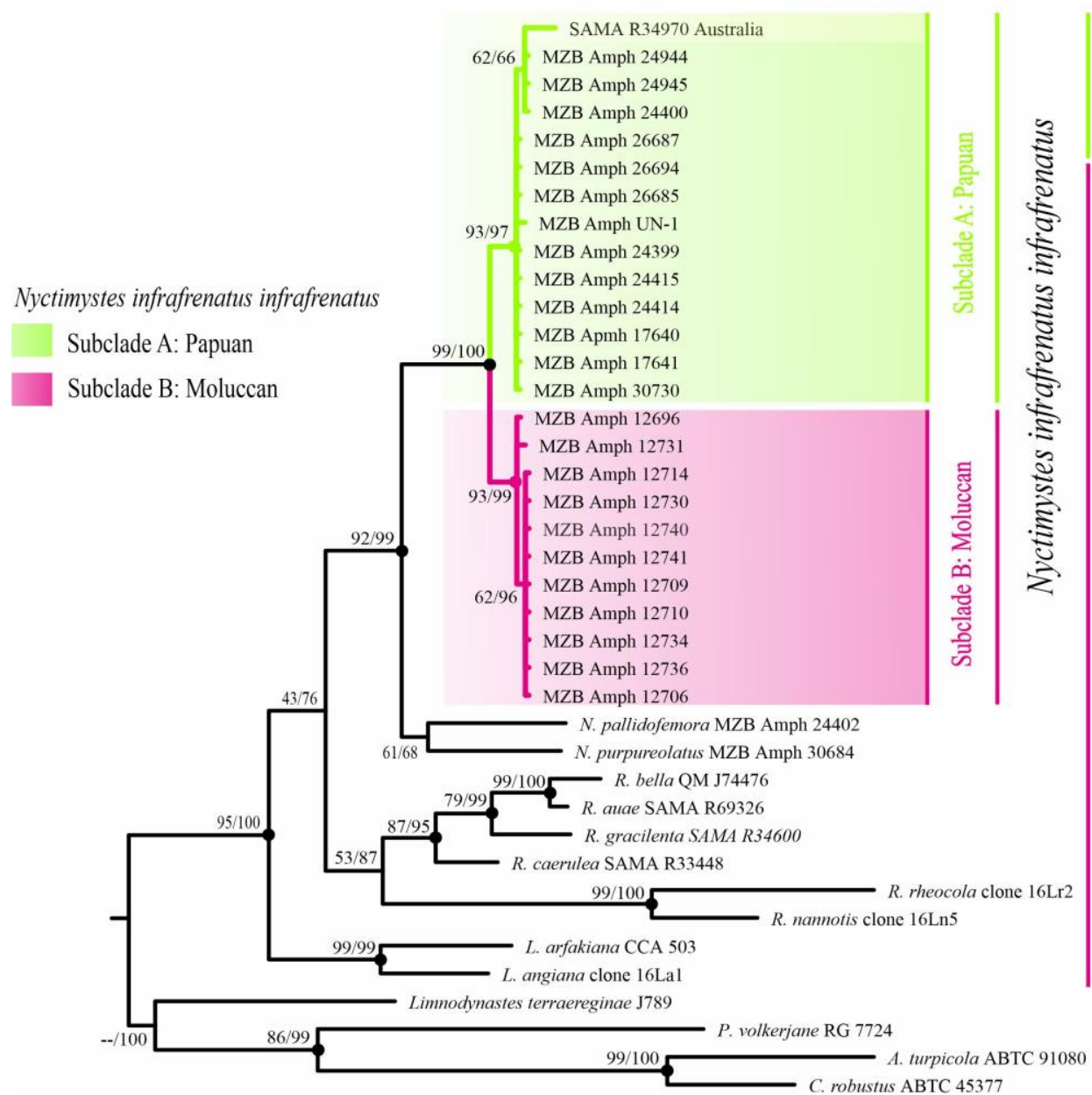

$\widetilde{1005} 16 \mathrm{~S}$ rRNA

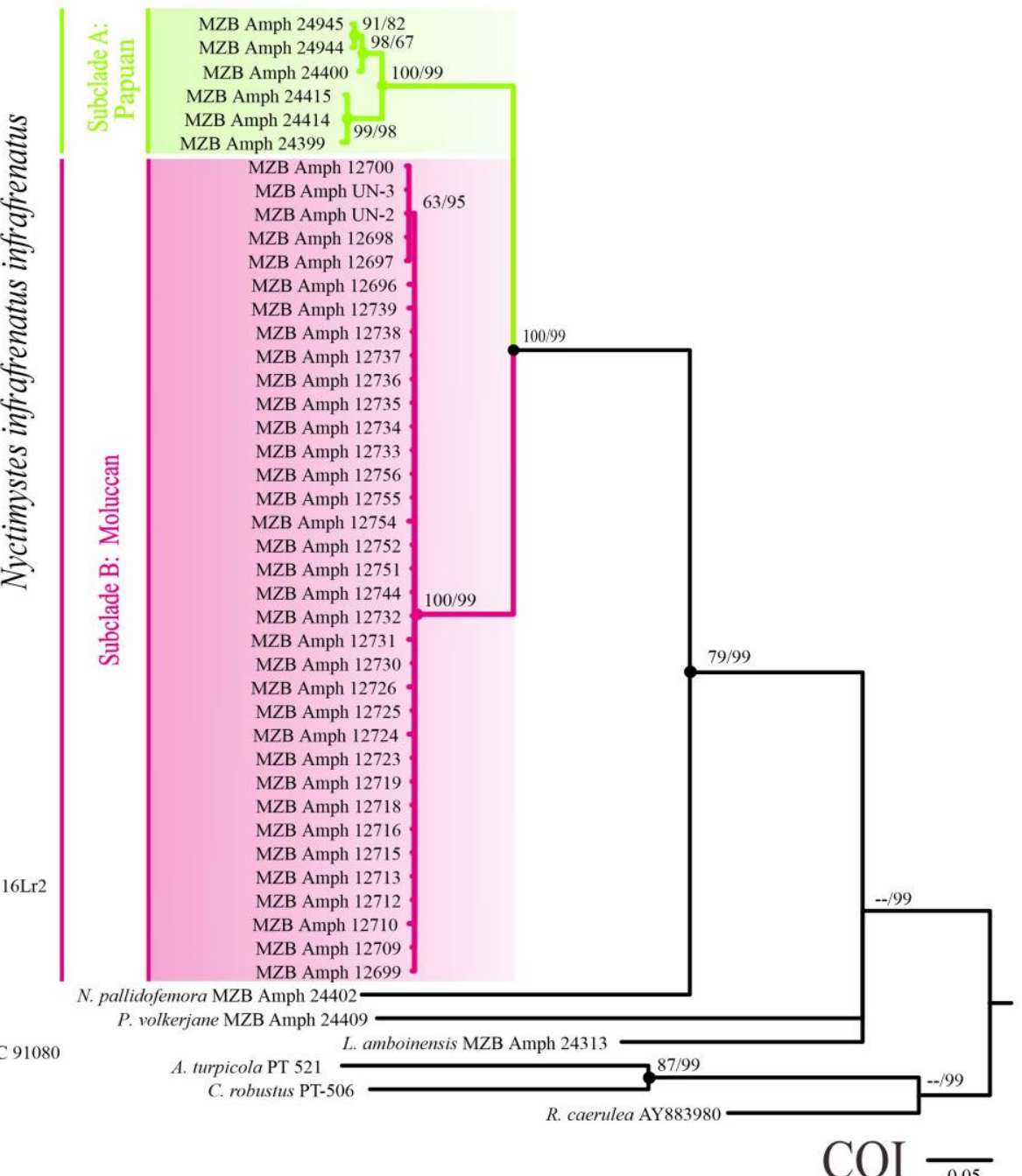

Figure 2. Bayesian phylogram of $419 \mathrm{bp}$ of $16 \mathrm{~S}$ rRNA and 555bp COI mitochondrial genes for samples of $N$. infrafrenatus and outgroup species. Numbers above branches represent bootstrap supports for ML and Bayesian Inferences (BI). Closed circles indicate nodes with significant bootstrap supports for ML (>70\%) inferences and Bayesian Inference (BI>95\%) 
The genetically separated populations of $N$. infrafrenatus infrafrenatus occurred in two biogeographic regions. Subclade A from Papua occurs in Australo-Papuan region. Subclade B is from Halmahera, the largest island of Moluccas (Setiadi et al. 2010) and Tidore, represented Wallacean, one of biodiversity hotspots in Indo-Australia archipelago (Myers et al. 2000; Lohman et al. 2011). Wallacea is broadly defined by Wallace's line in the west and Lydakker's Line in the east (Hall 1998; 2002; 2009; 2013; Michaux 2010; Lohman et al. 2011). It is a transition zone between Sahul and Sundaland. Halmahera and Papua (New Guinea) were the part of Australian zoogeographic region (Wallace 1876; Rueda et al. 2013) which were divided by Holt et al. (2013) into Australian and Oceanian including Moluccas, New Guinea, and Pacific Islands.

The genetic difference between two populations of $N$. infrafrenatus infrafrenatus might be a result of geological history of Papua and Moluccas. New Guinea and Moluccas, especially Halmahera, come from two different tectonic plates (Hall 1998; 2002; 2009; 2013; Michaux 2010; Lohman et al. 2011; Baldwin et al. 2012). New Guinea is a part of the Australian plate (Hall 2002; 2009; Baldwin et al. 2012) whilst Halmahera is a part of the Philippine Sea plate (Michaux 2010; Baldwin et al. 2012). During the Neogene, Halmahera was probably close to New Guinea in the north margin of Australian plate about 20-15 mya, small pieces of landmass only appeared in the northern part of current New Guinea. Most of New Guinea, region of the Bird Head and Halmahera were on carbonate platform. Halmahera's landmass first appeared about 10 mya (Hall 1998; 2002; 2009; 2013; Lohman et al. 2011). Halmahera has been isolated from the mainland probably early during this process (Setiadi et al. 2010). Therefore, considering the level of genetic distance, the presence of $N$. infrafrenatus on Halmaera probably result from oversea dispersal during Late Pliocene or Pleistocene, followed by isolation.

Concerning the low divergence between Australian and Papuan samples of $N$. infrafrenatus (1.3-1.5\% in $16 \mathrm{~S}$ rRNA), a vicariance event is likely since. We know that New Guinea and Australia were connected recently. The lowest sea level during the last maximum glaciation (about $18000 \mathrm{BP}$ ) was up to $125 \mathrm{~m}$ below the present sea level (Hantoro et al. 1995). The exposed area, called Sahul shelf, was covered by humid lowland tropical forest (Hantoro et al. 1995). Woodland-open forest covered the southern part of New Guinea to the eastern part of Australia and was followed by grassland-shrubland on most of northern Australian side of Sahul shelf (Van der Kaars 1991). The Sahul shelf could become the land bridge of fauna distribution between Australia and New Guinea. There was also Pleistocene river system (Voris 2000) which was important to support faunal exchange through the Sahul shelf. At the end of glaciation, sea level rose separated New Guinea and Australia until present (Voris 2000; Yokoyama et al. 2001).

The wide distribution of $N$. infrafrenatus is often believed to have resulted from human-assisted transport because this species is commensal which can be found in the garden and urban area (Vences et al. 2003; Menzies 2006; Hamidy and Mulyadi 2007). Distinct genetic differences between Papuan and Moluccan populations could support the dispersal theory. Moreover, Halmahera is an oceanic island that has not been in contact with the mainland of New Guinea or Australia. Therefore, N. infrafrenatus most likely dispersed from New Guinea to Halmahera overseas. In Wallacean herpetofauna, Karin et al. (2020) found that northern water dragon (Tropicagama temporalis) colonized the Moluccan islands of Babar, Kur, Tam, and Tanimbar from the New Guinea rather than from Australia via overwater dispersal.
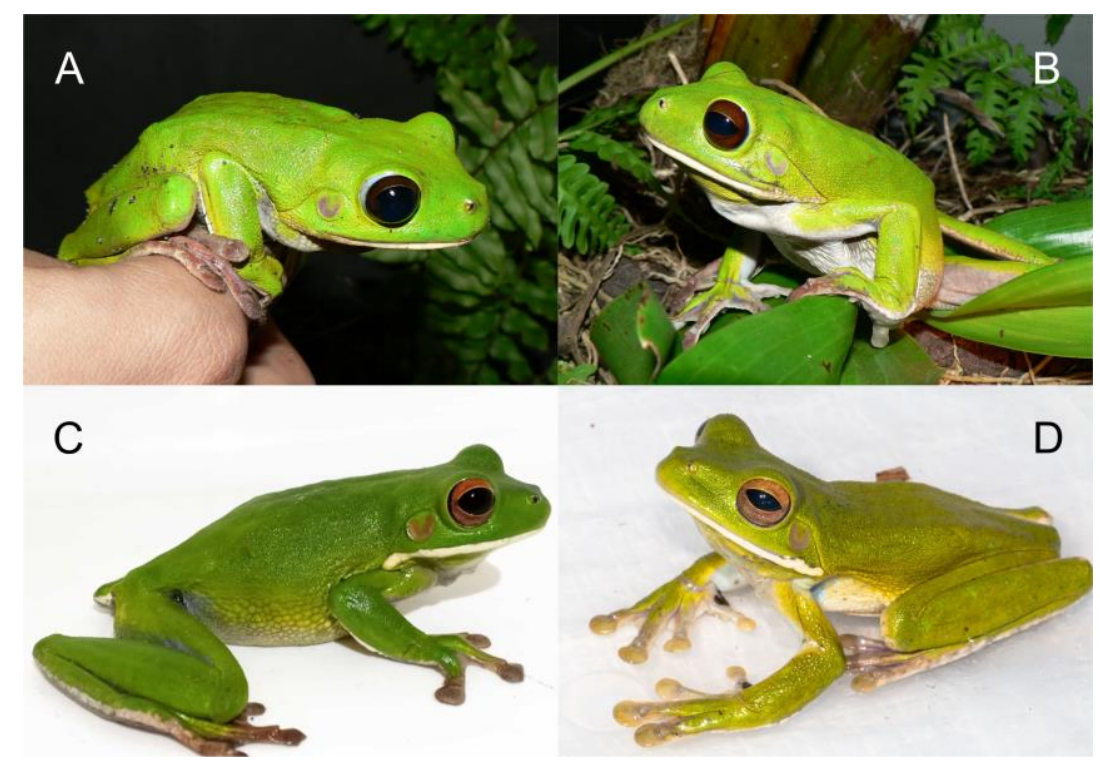

Figure 3. Nyctimystes infrafrenatus infrafrenatus from the Moluccas of Ternate (A) and Halmahera (B) has the thinner white lip than their counterparts from the Papuan of Timika (C) and Lengguru (D). Live specimens photographed by M. Iqbal Setadi (A,B), Amir Hamidy (C) and Antoine Fouquet (D) 

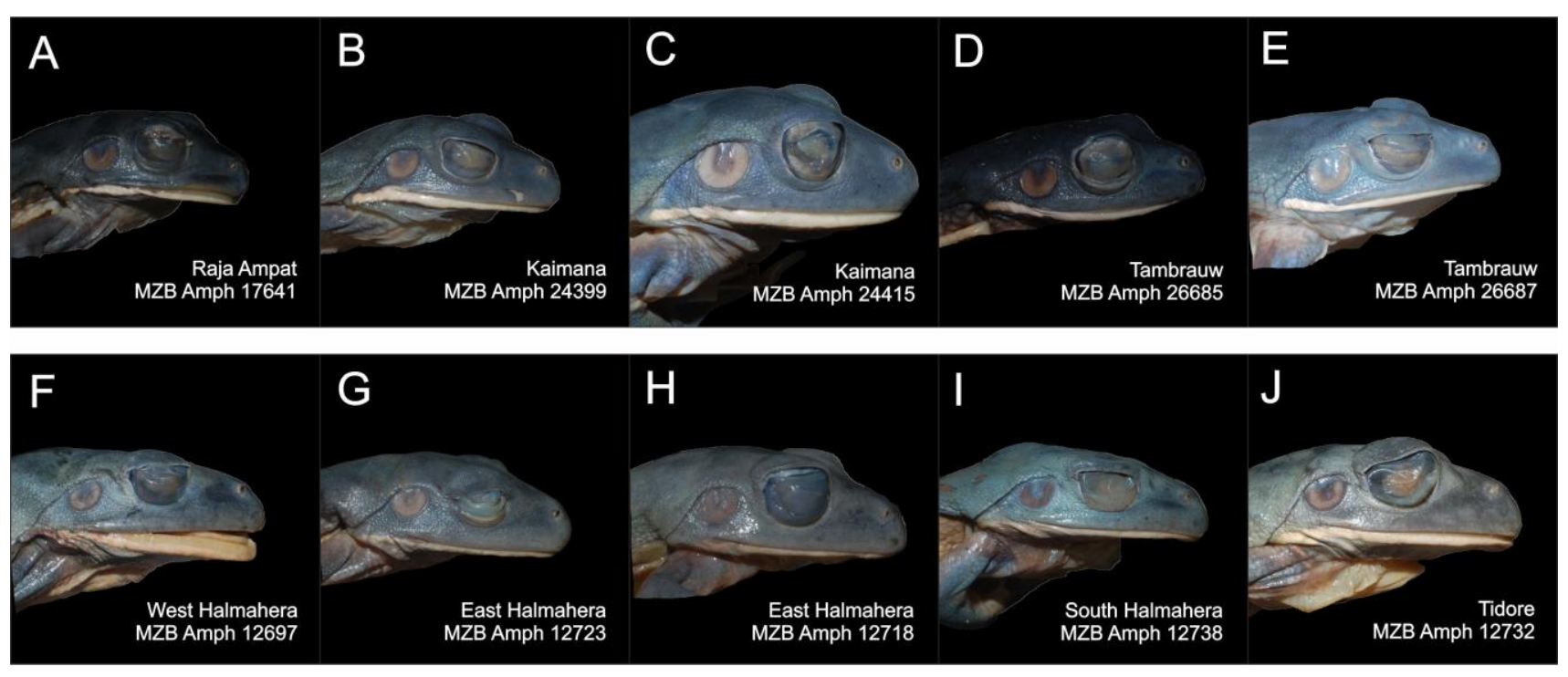

Figure 4. Specimens of Nyctimystes infrafrenatus infrafrenatus in Museum Zoologicum Bogoriense (MZB). A-E from Papua, F-J from Moluccas

Finally, our finding showed that the populations of a single species Nyctimystes infrafrenatus which are geographically separated form distinct phylogenetic subclades with genetic distance in the range of species level and phenotypic differences (even though desserving more examination). We propose to restrict the nominal species Nyctimystes infrafrenatus (Günther, 1867) to the Papuan and Australian populations and to resurrect Nyctimystes tennuigranulatus (Boettger 1895) for the northern Moluccan populations. Further studies including samples from Ambon (southern Moluccas), where the Hyla dolichopsis (Cope, 1867) was described is needed to determine the taxonomic status of the southern Moluccan population.

\section{ACKNOWLEDGEMENTS}

We thank The Indonesian Institute of Sciences (LIPI) and the French Institut de Recherche pour le Développement (IRD) for Lengguru 2014 Project (www.lengguru.org) that supports this works. Thank you to Tambrauw Expedition DIPA Pusat Penelitian Biologi LIPI 2016 and DNA Barcoding Fauna Indonesia DIPA Pusat Penelitian Biologi LIPI 2018. We also thank anonymous reviewers for improving an earlier version of the manuscript. TNS thanks to Lembaga Pengelola Dana Pendidikan (LPDP) Ministry of Finance of the Republic of Indonesia for scholarship and research funding. TNS also thanks to Achmad Alfiyan for helping in data processing and Syaripudin for guidance in specimen examination. All authors contributed equally to the manuscript.

\section{REFERENCES}

Andersson LG. 1916. Results of Dr. E. Mjöberg's Swedish scientific expeditions to Australia 1910-1913. I. 9. Batrachians from Queensland. K Sven Vetensk Akad Hand 52: 1-20. DOI: 10.5962/bhl.part.1499.

Baldwin SL, Fitzgerald PG, Webb LE. 2012. Tectonic of the New Guinea region. Ann Rev Earth Planet Sci 40: 495-520. DOI: 10.1146/annurev-earth-040809-152540.

Boettger O. 1895. Liste der reptilien und Batrachier der Insel Halmaheira nach den Sammlungen Prof. Dr. W. Kükenthal's. Zool Anz 18: 129138.

Boulenger GA. 1882. Catalogue of the Batrachia Salientia s. Ecaudata in the Collection of the British Museum. $2^{\text {nd }}$ ed. Taylor and Francis, London.

Boulenger GA. 1898. Fourth report on additions to the Batrachian collection in the Natural-History Museum. Proc Zool Soc Lond 1898: 473-482. DOI: 10.1111/j.1096-3642.1898.tb03168.x.

Boulenger GA. 1912. On some treefrogs allied to Hyla caerulea, with remarks on noteworthy secondary sexual characters in the family Hylidae. Zool Jahrb Abt Syst Geog Biol Tiere 15: 211-218.

Boulenger GA. 1915. Description of a new tree-frog of the genus Hyla discovered by Mr. A.E. Pratt in the Arfak Mountains, Dutch New Guinea. Ann Mag Nat Hist Series 8 16: 402-404. DOI: 10.1080/00222931508693731.

Brongersma LD. 1948. Frogs and snakes from the island of Morotai (Moluccas). Zool Meded 29: 306-310.

Cope ED. 1867. On the families of the raniform Anura. J Acad Nat Sci Phila Series 26: 189-206.

Darst CR, Cannatella DC. 2004. Novel relationships among hyloid frogs inferred from $12 \mathrm{~S}$ and $16 \mathrm{~S}$ mitochondrial DNA sequences. Mol Phylogenet Evol 31: 462-475. DOI: 10.1016/j.ympev.2003.09.003.

Dubois A, Fretey T. 2016. A new nomen for a subfamily of frogs (Amphibia, Anura). Dumerilia 6: 17-23.

Duellman WE, Marion AB, Hedges SB. 2016. Phylogenetics, classification, and biogeography of the treefrogs (Amphibia: Anura: Arboranae). Zootaxa 4104: 1-109. DOI: 10.11646/zootaxa.4104.1.1.

Environmental Systems Research Institute (ESRI). 2014. ArcGIS Desktop Help 10.3 Geostatistical Analyst. Redlands, California.

Folmer O, Black M, Hoeh W, Lutz R, Vrijenhoek R. 1994. DNA primers for amplification of mitochondrial cytochrome $\mathrm{c}$ oxidase subunit I from diverse metazoan invertebrates. Mol Mar Biol Biotechnol 3: 294-299. 
Fonte LFM, Mayer M, Lötters S. 2019. Long-distance dispersal in amphibians. Front Biogegr 2019: 1-14. DOI: 10.21425/F5FBG44577.

Fouquet A, Gilles A, Vences M, Marty C, Blanc M, Gemmell NJ. 2007. Underestimation of species richness in Neotropical frogs revealed by mtDNA analyses. PLoS ONE 2 (10): e1109. DOI 10.1371/journal.pone.0001109.

Frost DR. 2020. Amphibian species of the world: An online reference. Version

https://amphibiansoftheworld.amnh.org/Amphibia/Anura/Pelodryadid ae/Pelodryadinae/Nyctimystes/Nyctimystes-infrafrenatus.

Fry DB. 1913. A re-examination of Macleay's New Guinea and Queensland frog types. Mem Queensl Mus 2: 46-50.

Fry DB. 1915. Herpetological notes. Proc R Soc Qld 27: 60-95.

Günther ACLG. 1867. Additions to the knowledge of Australian reptiles and fishes. Ann Mag Nat Hist Series 3 20: 45-68. DOI: $10.1080 / 00222936708562716$

Günther R. 2003. Sexual colour dimorphism in ranid frogs from New Guinea: Description of two new species (Amphibia, Anura, Ranidae) Mitt Mus Naturkunde Berl Zool Reihe 79: 207-227. DOI 10.1002/mmnz.4850790202.

Hall R, Nichols GJ. 1990. Terrane amalgamation in the Philippine Sea margin. In: Kono M, Burchfiel BC (eds). Tectonic of Eastern Asia and Western Pacific Continental Margin. Tectonophysics. 181: 207 222. DOI: 10.1016/0040-1951(90)90017-3.

Hall R. 1998. The plate tectonics of Cenozoic Southeast Asia and the distribution of land and sea. In: Hall R, Holloway JD (eds) Biogeography and Geological Evolution of Southeast Asia. Backhuys Publishers, Leiden.

Hall R. 2002. Cenozoic geological and plate tectonic evolution of SE Asia and the SW Pacific: Computer-based reconstructions, model and animations. J Asian Earth Sci 20: 353-431. DOI: 10.1016/S1367 9120(01)00069-4.

Hall R. 2009. Southeast Asia's changing palaeogeography. Blumea 54: 148-161. DOI: $10.3767 / 000651909$ X475941.

Hall R. 2013. The paleogeography of Sundaland and Wallacea since the Late Jurassic. J Limnol 72(2): 1-17. DOI: 10.4081/jlimnol.2013.s2.e1.

Hamidy A, Mulyadi. 2007. Herpetofauna on Waigeo Island. Research Center for Biology, Indonesian Institute of Sciences, Bogor.

Hantoro WS, Faure H, Djuwansah R, Faure-Denard L, Pirazzoli PA 1995. The Sunda and Sahul continental platform: Lost land of the last glacial continent in S.E. Asia. Quat Intl 29/30: 129-134. DOI: 10.1016/1040-6182(95)00015-B.

Hedges SB. 1994. Molecular evidence for the origin of birds. Proc Natl Acad Sci USA. 91: 2621-2624. DOI: 10.1073/pnas.91.7.262.

Hillis DM, Bull JJ. 1993. An empirical test of bootstrapping as a method for assessing confidence in phylogenetic analysis. Syst Biol 42:182 192. DOI: $10.1093 /$ sysbio/42.2.182

Hillis DM, Mable BK, Larson A, Davis SK, Zimmer EA. 1996. Nucleic acids IV: sequencing and cloning. In: Hillis DM, Mable BK, Moritz C (eds). Molecular Systematics. Sinauer, Sunderland. DOI $10.2307 / 1447682$.

Holt B, Lessard J, Borregaard MK, Fritz SA, Araujo MB, Dimitrov D, Fabre P, Graham C, Graves GR, Jonsonn KA, Nogues-Bravo D, Wang Z, Whittaker RJ, Fjeldsa J, Rahbek C. 2013. An update of Wallace's zoogeographic regions of the world. Science 339 (6115) 74-78. DOI: $10.1126 /$ science. 1228282

Horst R. 1883. On new and little-known frogs from the Malayan archipelago. Not Leyden Mus 5: 235-244.

ICZN [International Commission on Zoological Nomenclature]. 1999. International Code of Zoological Nomenclature, 4th ed. The International Trust for Zoological Nomenclature, London.

Iskandar DT, Colijn E. 2001. Checklist of Southeast Asian herpetofauna I amphibians. Treubia 31: 1-133.

Iskandar DT, Mumpuni, Hero J, Retallick R, Richards S. 2017. Nyctimystes infrafrenatus (amended version of 2004 assessment). The IUCN Red List of Threatened Species 2017: e.T41095A114114070. DOI: 10.2305/IUCN.UK.2017-1.RLTS.T41095A114114070.en.

Karin BK, Stubss AL, Arifin U, Bloch LM, Ramadhan G, Iskandar DT, Arida E, Reilly SB, Kusnadi A, Mcguire JA. 2018. The herpetofauna of the Kei Islands (Maluku, Indonesia): Comprehensive report on new and historical collections, biogeographic patterns, conservation concerns, and an annotated checklist of species from Kei Kecil, Ke Besar, Tam, and Kur. Raffles Bull Zool 66: 704-738. DOI: 10.1655/Herpetologica-D-19-00033.

Karin BK, Stubss AL, Arifin U, Iskandar DT, Arida E, Austin CC, McGuire JA. 2020. Crossing Lydekker's Line: Northern water dragons (Tropicagama temporalis) colonized the Moluccan Islands of Indonesia from New Guinea. Herpetologica 76 (3): 344-350.

Koch A, Arida E, Riyanto A., BÖhme W. 2007. Islands between the Realms: A revised checklist of the herpetofauna of the Talaud archipelago, Indonesia, with a discussion about its biogeographic affinities. Bonn Zool Beitr 56: 107-129.

Kraus F. 2018. Taxonomy of Litoria graminea (Anura: Hylidae), with description of two closely related new species. Zootaxa 4457(2): 264284. DOI: $10.11646 /$ zootaxa.4457.2.3.

Kumar S, Stecher G, Li M, Knyaz C, Tamura K. 2018. MEGA X: Molecular evolutionary genetics analysis across computing platforms. Mol Biol Evol 35:1547-1549. DOI: 10.1093/molbev/msy096.

Leaché AD, Reeder TW. 2002. Molecular systematics of the eastern fence lizard (Sceloporus undulatus): A comparison of parsimony, likelihood, and Bayesian approaches. Syst Biol 51: 44-68. DOI: $10.1080 / 106351502753475871$.

Liem DSS. 1974. A review of the Litoria nannotis species group, and a description of a new species of Litoria from northern Queensland, Australia (Anura: Hylidae). Mem Queensl Mus 17: 151-168.

Lohman DJ, de Bruyn M, Page T, von Rintelen K, Hall R, Ng PKL, Shih H, Carvalho GR, von Rintelen T. 2011. Biogeography of the IndoAustralian Archipelago. Ann Rev Ecol Evol Syst 42: 205-226. DOI: 10.1146/annurev-ecolsys-102710-145001.

Loveridge A. 1948. New Guinean reptiles and amphibians in the Museum of Comparative Zoology and United States National Museum. Bull Mus Comp Zool 101: 305-430.

Macleay WJ. 1878. The batrachians of the "Chevert" Expedition. Proc Linn Soc NSW 2: 135-138.

Mahony M, Knowles R, Foster R, Donnellan S. 2001. Systematics of the Litoria citropa (Anura: Hylidae) complex in Northern New South Wales and Southern Queensland, Australia, with the description of a new species. Rec Aust Mus 53: 37-48. DOI: 10.3853/j.00671975.53.2001.1322

McDonald KR, Rowley JJ, Richards SJ, Frankham GJ. 2016. A new species of treefrog (Litoria) from Cape York Peninsula, Australia. Zootaxa 4171: 153-169. DOI: 10.11646/zootaxa.4171.1.6.

Menzies JI, Tyler MJ. 2004. Litoria gracilenta (Anura: Hylidae) and related species in New Guinea. Aust J Zool 52: 191-214. DOI: 10.1071/ZO03008.

Menzies JI. 2006. The frogs of New Guinea and the Solomon Islands. Pensoft, Sofia.

Michaux B. 2010. Biogeology of Wallacea: Geotectonic models, areas of endemism and natural biogeographical units. Biol J Linn Soc 101: 193-212. DOI: 10.1111/j.1095-8312.2010.01473.x.

Myers N, Mittermeier RA, Mittermeier CG, da Fonseca GAB, Kent J. 2000. Biodiversity hotspots for conservation priorities. Nature 403: 853-945. DOI: $10.1038 / 35002501$

Nei M, Kumar S. 2000. Molecular Evolution and Phylogenetics. Oxford University Press, New York.

Nugroho H, Riyanto A, Wiantoro S, Santika Y, Irham M. 2019. Tambraw Expedition: A slice of heaven in the land of Papua. LIPI Press, Jakarta

Oliver LA, Prendini E, Kraus F, Raxworthy CJ. 2015. Systematics and biogeography of the Hylarana frog (Anura: Ranidae) radiation across tropical Australasia, Southeast Asia, and Africa. Mol Phylogenet Evol 90: 176-192. DOI: 10.1016/j.ympev.2015.05.001.

Oliver PM, Richards SJ, Tjaturadi B, Iskandar DT. 2007. A new large green species of Litoria (Anura: Hylidae) from western New Guinea. Zootaxa 1519: 17-26. DOI: 10.11646/zootaxa.1519.1.2.

Peloso PLV, Frost D, Richards SJ, Rodrigues MT, Donellan S, Matsui M, Raxworthy CJ, Biju SD, Lemmon EM, Lemmon AR. Wheeler WC. The impact of anchored phylogenomics and taxon sampling on phylogenetic inference in Narrow-mouthed frogs (Anura, Microhylidae). Cladistic 0: 1-28.

Peters WCH, Doria G. 1878. Catalogo dei rettili e dei batraci raccolti da O. Beccari, L.M. D'Albertis e A.A. Bruijn nella sotto-regione AustroMalese. Ann Mus Civ Stor Nat Genova 13: 323-450.

Peters WCH. 1869. Über neue Saurier (Chaunolaemus multicarinatus, Tropidolepisma richardi und Gymnodactylus steudneri) und Batrachier (Cyclorhamphus fasciatus und Hyla gracilenta). Ber Akad Wis Berlin 1869: 786-790.

Prafiadi S, Kurniawan N, Hamidy A. 2016. Species diversity of the Papuan green tree frog Litoria infrafrenata infrafrenata Tyler, 1971 in the Wallacea and Indo-Australian archipelago. J-PAL 7 (1): 33-43.

Pyron RA, Wiens JJ. 2011. A large-scale phylogeny of amphibia including over 2800 species, and a revised classification of extant 
frogs, salamanders, and caecilians. Mol Phylogenet Evol 61: 543-583. DOI: $10.1016 /$ j.ympev.2011.06.012.

Ramsay EP. 1878. Description of a new species of Pelodryas, from New Ireland. Proc Linn Soc NSW 2: 28-30. DOI: 10.5962/bhl.part.22203. [Australian]

Ronquist F, Huelsenbeck JP. 2003. MrBayes 3: Bayesian phylogenetic inference under mixed models. Bioinformatics 19(12): 1572-1574. DOI: 10.1093/bioinformatics/btg180.

Rosauer D, Lafffan SW, Crisp MD, Donnellan SC, Cook LG. 2009 Phylogenetic endemism: A new approach for identifying geographical concentrations of evolutionary history. Mol Ecol 18: 4061-4072. DOI: 10.1111/j.1365-294X.2009.04311.x.

Rueda M, Rodriguez MA, Hawkins BA. 2013. Identifying global zoogeographical regions: Lessons from Wallace. J Biogeogr 40: 2215-2225. DOI: $10.1111 / \mathrm{jbi} .12214$.

Schauble CS, Moritz C, Slade RW. 2000. A molecular phylogeny for the frog genus Limnodynastes (Anura: Myobatrachidae). Mol Phylogenet. Evol 16(3): 379-391. DOI: 10.1006/mpev.2000.0803.

Schlegel H. 1837. Abbildungen neuer oder unvollständig bekannter Amphibien, nach der Natur oder dem Leben entworfen, herausgegeben und mit einem erläuternden Texte begleitet. Part 1. Arnz \& Co, Düsseldorf. DOI: 10.5962/bhl.title.95393.

Setiadi MI, Hamidy A, Abidin Z, Susanto D, Brown RM, Peterson AT, Li X, Evans BJ. 2010. Genetic structure of herpetofauna on Halmahera Island, Indonesia: Implications for Aketajawe-Lolobata National Park. Conserv Biol 24(2): 553-562. DOI: 10.1111/j.15231739.2009.01384.x.

Setiadi MI, Hamidy A. 2006. Herpetofauna species on Halmahera Island. Center for Biodiversity and Conservation, Universitas IndonesiaResearch Center for Biology, Indonesian Institute of Sciences, Cibinong, Bogor. [Indonesian].

Stejneger L. 1916. New generic name for a tree-toad from New Guinea. Proc Biol Soc Washington 29: 86.

Tanabe AS. 2007. Kakusan: A computer program to automate the selection of a nucleotide substitution model and the configuration of a mixed model on multilocus data. Mol Ecol Notes 7: 962-964. DOI $10.1111 / \mathrm{j} .1471-8286.2007 .01807 . x$.

Tschudi JJv. 1838. Classification der Batrachier mit Berücksichtigung der fossilen Thiere dieser Abtheilung der Reptilien. Petitpierre, Neuchâtel. DOI: 10.5962/bhl.title.4883. [Germany]
Tyler MJ, Davies M. 1978. Species-groups within the Australopapuan Hylid Frog Genus Litoria Tchudi. Aust J Zool 63:1-47. DOI: 10.1071/AJZS063.

Tyler MJ. 1971. The phylogenetic significance of vocal sac structure in hylid frogs. University of Kansas Publications. Mus Nat Hist 19: 319360. DOI: $10.5962 /$ bhl.part.15451.

Van der Kaars WA. 1991. Palynology of eastern Indonesian marine piston-cores: A late quaternary vegetational and climatic record for Australasia. Palaeogeography 85: 239-302. DOI: 10.1016/00310182(91)90163-L.

Van Kampen PN. 1919. Die Amphibienfauna von Neu-Guinea. Bijdragen tot de Dierkunde Cont Zool 21: 51-56. DOI: 10.1163/2666064402101004.

Van Kampen PN. 1923. The Amphibia of the Indo-Australian Archipelago. E. J. Brill Ltd., Leiden.

Vences M, Thomas M, Van der Meijden A, Chiari Y, Vieites D. 2005. Comparative performance of the $16 \mathrm{~S}$ rRNA gene in DNA barcoding of amphibians. Front Zool 2(1): 5. DOI: 10.1186/1742-9994-2-5.

Vences M, Vieites DR, Glaw F, Brinkmann H, Kosuch J, Veith M, Myer A. 2003. Multiple overseas dispersal in amphibians. Proc R Soc Lond 270: 2435-2442. DOI: 10.1098/rspb.2003.2516.

Voris HK. 2000. Maps of Pleistocene sea levels in Southeast Asia: shorelines, river systems and time durations. J Biogeogr 27: 11531167. DOI: 10.1046/j.1365-2699.2000.00489.x.

Wallace AR. 1876. The Geographical Distribution of Animals, Vols 1 \& 2. Harper \& Brothers, New York.

Werner F. 1898. Vorläufige Mittheilung über die von Herrn Prof. F. Dahl im Bismark-Archipel gesammelten Reptilien und Batrachier. Zool Anz 21: 552-556. [Germany]

White J. 1790. Journal of a Voyage to New South Wales with Sixty-five Plates of Non-descript Animals, Birds, Lizards, Serpents, Curious Cones of Trees and Other Natural Productions. J Debrett, London. DOI: 10.5962/bhl.title.118604.

Wiens JJ, Kuczynski CA, Hua X, Moen DS. 2010. An expanded phylogeny of treefrogs (Hylidae) based on nuclear and mitochondrial sequence data. Mol Phylogenet Evol 55: 871-882. DOI: 10.1016/j.ympev.2010.03.013.

Yokoyama Y, Purcell A, Lambeck K, Johnston P. 2001. Shore-line reconstruction around Australia during the Last Glacial Maximum and Late Glacial Stage. Quat Intl 83-85: 9-18.DOI: 10.1016/S10406182(01)00028-3. 